\title{
The Social Responsibility Education in China's Business Schools against the Background of Globalization: Trends, Problems and Countermeasures
}

\author{
Yanhai Zhao ${ }^{1, a}$, Wei Chu ${ }^{2, b}$ \\ ${ }^{1}$ School of Management, Lanzhou University, Lanzhou, 730000, China \\ ${ }^{2}$ School of Management, Lanzhou University, Lanzhou, 730000, China \\ aemail: yhzhao@Izu.edu.cn, bemail: chuw12@Izu.edu.cn
}

Keywords: Business School; Social Responsibility; Stake-holder; Globalization

\begin{abstract}
This paper studies the present situation of business school in regard to social responsibility education, with its development trends, challenges and opportunities. From a brief literature review, the paper has synthesized the developing trends as well the existing problems. Finally, through stakeholder approach, some countermeasures are proposed in regard to curriculum development, teaching and evaluation method, and school running pattern as well.
\end{abstract}

\section{Introduction}

Twenty years have passed by since the beginning of MBA education in China's business schools in 1991. As an essential ingredient of higher education system in China, business schools assume the important tasks of training administrative talents. In recent days, a series of business scandals have attracted the public attention, which arose some blames for business schools' incompetence to train responsible managers. In this content, business schools' role in the education of social responsibility draws varied interest and accents. This paper studies the present situation of business school in regard to the education of social responsibility against the background of globalization. It first resumes the developing trends of business schools in China with its opportunities and challenges. Then the existing problems of business education of corporate social responsibility are analyzed. Finally some countermeasures are suggested by way of stakeholder approach.

\section{Corporate Social Responsibility and Business School}

Corporate Social Responsibility (CSR) is the legal liability and moral obligations that the enterprises undertake to meet stakeholders' expectations. The concept was first introduced by Oliver Sheldon, when he studied the American companies in 1923. He supposed that the CSR should include moral elements [1]. Later, other scholars have continued the study in this filed, which mainly include the stakeholder theory, triple bottom line, pyramid model, etc. With the constant intensification of business schools' internationalization, the accreditation of business education quality has become one of comparative advantage for business schools in China. These standards are constituted by the accreditation standards of AACSB, EQUIS and AMBA, etc. And scholars and directors of business school in China have also noticed the significance of CSR education. Fanghua Wang, ex-director of Fudan's business school, for instance, pointed out that business schools should take the responsibilities of "role", "behavior" and "moral" [2]. But, while the concepts of CSR can help us to understand the importance of business schools' social responsibility, the two have significant differences, which are shown in the table below (Table I). 
Table I. Comparison of CSR and Business School's Social Responsibility

\begin{tabular}{|l|l|l|}
\hline \multirow{2}{*}{ Item } & \multicolumn{2}{|l|}{ Comparative Analysis } \\
\cline { 2 - 3 } Subject & Business school social responsibility schools & Enterprises \\
\hline Objective & To cultivate the students' sense of social responsibility & To improve the efficiency of the company \\
\hline Approach & Lecture and practice exercises & Company management and other events \\
\hline $\begin{array}{l}\text { Field of } \\
\text { action }\end{array}$ & $\begin{array}{l}\text { Curriculum about corporate ethics and social } \\
\text { responsibility }\end{array}$ & All kinds of business activities \\
\hline Stakeholder & $\begin{array}{l}\text { Government, school and competent departments, faculty } \\
\text { members, students, employer, strategic cooperative } \\
\text { partners, media, labor union organization, community, } \\
\text { non-governmental organization }\end{array}$ & $\begin{array}{l}\text { Government, employee, consumer, community, owner } \\
\text { include the individual shareholders, investment } \\
\text { institution and board of directors) }\end{array}$ \\
\hline $\begin{array}{l}\text { Evaluation } \\
\text { institution }\end{array}$ & AACSB, AMBA, EQUIS, etc. & ISO24000, SA8000, etc. \\
\hline
\end{tabular}

Sources: author

\section{Development Trends of China's Business Schools in Social Responsibility Education}

(1) Challenges of Business Schools’ Social Responsibility Education

China's business schools are facing the constant multiple pressures in the process of globalization. Firstly, foreign schools are now extracting a large number of talented students with better service and higher education quality. While introducing the sophisticated concepts and theories from the west, China's business schools are lack of advanced teaching resources and teaching methods to train innovative talents with international thoughts [3]. As thousands of foreign companies entered China, and as more and more Chinese firms are going abroad, business schools' efforts to meet the society's expectations are lagging behind.

Secondly, due to intense domestic competition, the international accreditation is a la mode among business schools in China. Among the 200 programs at MBA level throughout the country, students now enjoy more choices and accesses to various schools at home and abroad, the competition is becoming, to some extent, cut-throat. In the fierce competitive environment, business schools are required to meet the students' needs and to improve students' comprehensive quality. At the present, only a few schools have enjoyed the privilege. And as business education is highly homogeneous with the current business education system, the international accreditation is now considered as the ticket to the first level of development as well as guarantee to marketing success.

(2) Existing Problems of Business Schools' Social Responsibility Education

While the CSR is integrated into business education, the course is often categorized as selective or optional. But it is clear that the CSR can provide, at least, an approach to sustainable development in regard to management in general, and to various managerial disciplines in decision-making, execution and impact evaluation, etc. And even if the courses of CSR exist, there are few insightful cases of Chinese enterprises. Because of uncoordinated research efforts and of less academic accent, the cases developed in the west are either quite far from China's business, or the cases are written in such a manner that cannot be qualified as case, but only as story.

With the intensification of global commercial exchanges, and the internationalization of business education, China's business schools open their gate for various cooperation with foreign business schools. But this is submitted to red-tape and formalities both at home and abroad. In addition, some business schools adopt the model of “outsourcing”, while less attention has been devoted to curriculum integration. Thus some considerations arise for the overall quality of the business education. And as China's business schools are generally less famed than their counterpart in the west, they can perhaps learn from the case teaching method of Harvard Business School, which now make the most prominent features of Harvard Business School [4].Comparatively, less has been done in China, let alone to have some insights in regard to CSR education.

\section{The Countermeasures for the Development of China's Business Schools}

(1) Expectations from Stakeholders 
To assume their responsibility, and to offer education of quality, China's business schools should first of all take into account the expectations from key stake-holders. Once the stakeholders of business schools are categorized, distinctive strategies to meet their expectations should be sought, as what is shown in the following table (table II).

Table II. Business Schools’ Stakeholders and Communication Mechanism

\begin{tabular}{|c|c|c|c|}
\hline \multirow{2}{*}{ Stakeholders } & \multicolumn{3}{|l|}{ Communication Mechanism } \\
\hline & Communication method & Expectations to business school & Specific requirements \\
\hline Government & Focusing on the laws, policies, etc. & $\begin{array}{l}\text { Offering advice and suggestions for } \\
\text { government. }\end{array}$ & Building a harmonious society \\
\hline Employer & Regular contact and feedback & $\begin{array}{l}\text { Keeping continuous development of } \\
\text { business school. }\end{array}$ & $\begin{array}{l}\text { Providing outstanding students for } \\
\text { employers. }\end{array}$ \\
\hline $\begin{array}{l}\text { Strategic } \\
\text { Cooperative } \\
\text { Partners }\end{array}$ & The correspondence of files & $\begin{array}{l}\text { Expending the strategic areas of } \\
\text { cooperation }\end{array}$ & Sharing information and resources \\
\hline $\begin{array}{l}\text { School and } \\
\text { competent } \\
\text { departments }\end{array}$ & $\begin{array}{l}\text { Meetings, visits, reporting and daily } \\
\text { correspondence }\end{array}$ & $\begin{array}{l}\text { Building renowned school of } \\
\text { management }\end{array}$ & $\begin{array}{l}\text { Raising the level of scientific } \\
\text { research }\end{array}$ \\
\hline Students & Releasing information timely & $\begin{array}{l}\text { Providing the education of high } \\
\text { quality }\end{array}$ & $\begin{array}{l}\text { Setting up reasonable curricula and } \\
\text { bilingual English courses }\end{array}$ \\
\hline $\begin{array}{l}\text { Faculty } \\
\text { members }\end{array}$ & $\begin{array}{l}\text { Annual meeting, the rationalization } \\
\text { proposals, and conferences }\end{array}$ & $\begin{array}{l}\text { Providing more growth } \\
\text { opportunities and better welfare for } \\
\text { faculty }\end{array}$ & Providing opportunities for faculty \\
\hline Media & $\begin{array}{l}\begin{array}{l}\text { Notification publicity for major } \\
\text { events }\end{array} \\
\end{array}$ & Continued steady growth & $\begin{array}{l}\text { Major events brochure and website } \\
\text { of the school }\end{array}$ \\
\hline $\begin{array}{l}\text { Labor union } \\
\text { organization }\end{array}$ & $\begin{array}{l}\text { Taking part in major decisions and } \\
\text { faculty welfare programs }\end{array}$ & $\begin{array}{l}\text { Safe guarding the legitimate rights } \\
\text { of the faculty }\end{array}$ & $\begin{array}{l}\text { Organizing various cultural and } \\
\text { sports activities regularly }\end{array}$ \\
\hline Community & Conferences and visits & $\begin{array}{l}\begin{array}{l}\text { Promoting the prosperity } \\
\text { harmony } \\
\text { community }\end{array} \\
\text { development }\end{array}$ & Opening day activities every year \\
\hline $\begin{array}{l}\text { Non-governme } \\
\text { ntal } \\
\text { organization }\end{array}$ & $\begin{array}{l}\text { Participating in } \\
\text { public-spirited activities }\end{array}$ & $\begin{array}{l}\text { Promoting the development of } \\
\text { business school and local place }\end{array}$ & $\begin{array}{l}\text { Publishing the relevant reports and } \\
\text { circumstances }\end{array}$ \\
\hline
\end{tabular}

Sources: author

(2) Curriculum Development

As expectations and needs of stakeholders are different, curriculum should be developed accordingly, taken into account of regional, sector and industrial context. Moreover, the content of the curricula should contain frontiers of the latest theoretical achievements as well best business practices so that students can systematically understand the concept and practice CSR [5]. For Etzioni, business education appears not only fail to improve the moral character of the students but may actually weaken it [6]. Thus, business school should devote more attention to the education of CSR, which signify more efforts, more time and more practice in curriculum design and delivery.

(3) Teaching Methods

The purpose of case teaching is to help students learn problem-solving approaches and ideas from the cases. For students of China's business schools, most of the students are facing practical problems of China's special context. To integrate China's own CSR cases will certainly be necessary to enhance the overall curriculum delivery. And as the "cramming education" method is still used in many business schools, various effective ways cannot be used due to management formalities and limited conditions. Therefore, the teachers' teaching ability should be further strengthened to deliver CSR courses in a more effective and efficient manner. Lastly, CSR education is in a field of change and debate, which requires adapted combination of CSR theories and practices, because the discipline of CSR, itself, is under constant developments. Consequently, teachers of CSR should keep abreast the frontiers of academic achievements and theories, and apply these theories into teaching effectively [7]. This can help the students master the frontiers of management theories and apply these theories into the management practice in the future.

(4) Evaluation System

To encourage the interests of students, professors as well as employers, the recommanded scope of the theses should be broadened to contain such latest academic achievements and best practices. Especially in regard to CSR education, the real world business cases should be encouraged. And as CSR education requires theoretical study as well as business practice and moral considerations, 
business schools should set up a variety of testing methods, and calculate the final assessment results based proportionally. In addition to the examination and papers, video tapes, social practice, various initiative, collective contribution should also be included, as the best result of CSR education is not the academic score, but the consideration and effort to make our world a better place to live in.

(5) School-running Patterns

Enterprises are not only the receiver or consumer of business education; they can also be integrated in the education process in such field as curriculum development, case building, course delivery assessment, mobile class and internship. Only when business schools and enterprises work together to develop CSR education, can this particular course be of significant contrition to the society in general. Domestic business school should also strengthen their cooperation with international business schools, where schools of different context and background can learn from each other, and benefit the academic resources of the others. Exchanges can be at multiple level, students, professors, directors all can be integrated in the international cooperation.

\section{Conclusion}

In this paper, the situation and development trends of business schools' CSR education are summarized, and the existing problems are analyzed. Then from the analysis of business school's stakeholder, their category and their expectations, we have provided some countermeasures to strengthen CSR education by way of curriculum development, teaching methods, school running patterns, and evaluation system. To give the CSR education in China's business schools a full play; business schools should devote more attention to the CSR education through adapted curriculum, diversification of teaching methods, and effective stakeholder cooperation. Business schools are now in a changing globalized world. To succeed, and to contribute to the overall development of the country, region, city and community where they are located, where they operate, business schools have still a long way to go. CSR education may serve as both an approach to differentiation but as a strategy of integration and anticipation.

\section{Acknowledgement}

In this paper, the research was sponsored by the Chinese Fundamental Research Funds for the Central Universities (Project No. 11LZUJBWZY052) and Course Construction Project of Lanzhou University (Project No. 13SMJXYJ001).

\section{References}

[1] Ying Chen, Theory and Practice of Corporate Social Responsibility, Beijing: Economy and Management Press, 2009.

[2] Si Li, “The social responsibility of business school: the viewpoint of China," Wen Hui News, Nov. 2008.

[3] Lingyu Huang, Xiulian Li, and Jingtao Wang, "Designs and practices on personnel cultivation of internationalized higher education--a case study on International Business School of Dalian Nationalities University,” Journal of Dalian Nationalities University, Issue. 4, pp. 430-432, 2012.

[4] Chao Lang, "Shape special brand image of business school,” New Thinking, Issue. 6, pp. 76-79, 2012.

[5] Yue Qiu and Yiming Wu, "Business science education and Corporate Social Responsibility education: challenge, present situation and optimized countermeasure,” Journal of Jiangxi Youth Vocational College, Vol.21, Issue. 3, pp. 40-43, 2011.

[6] Etzioni, “When it comes to ethics B-schools get an F,” Washington Post, Aug. 2002, pp. B4.

[7] Bin Huang, "The comparative analysis and enlightenment of domestic and overseas business science education development," Foreign Economic Relations and Trade, Issue. 6, pp. 133-135, 2012. 